\title{
Jurist-Diction
}

Volume 4 No. 5, September 2021

\section{Tanggung Gugat Konsultan Pengawas Konstruksi Dalam Pekerjaan Terintegrasi Pengadaan Barang/Jasa Pemerintah}

\author{
Intan Nurmahani \\ nurmahaniintan@gmail.com \\ Universitas Airlangga
}

\begin{abstract}
How to cite:
Intan Nurmahani, 'Tanggung Gugat Konsultan Pengawas Konstruksi Dalam Pekerjaan Terintegrasi Pengadaan Barang/Jasa Pemerintah' (2021) Vol. 4 No. 5 JuristDiction.
\end{abstract}

Histori artikel:

Submit 21 Juli 2021;

Diterima 15 Agustus 2021;

Diterbitkan 1 September 2021

DOI:

10.20473/jd.v4i5.29819

p-ISSN: 2721-8392

e-ISSN: $2655-8297$

\section{Abstract}

Public Procurement has an important role in achieving the goals of the Indonesian people as stated in the Constitution. Especially in the development of infrastructure because the existence of adequate infrastructure will move the wheels of the economy even better and economic equality throughout Indonesia. Integrated construction work is a combination of construction work and consultancy services. Every construction carried out by the service provider must get technical supervision in the field. Field supervision must be carried out by placing supervisory experts according to the needs and complexity of the work. In this case the supervisory consultant is generally tasked with overseeing construction work with the aim of controlling the completion of the work process and minimizing irregularities that occur in the procurement contract. The method of approach used in this research is the statute approach, case approach, and conceptual approach to assessing legal issues that occur, namely the accountability of supervisory consultants in integrated work.

Keywords: Integrated Construction; Supervisory Consultant; Public Procurement.

\begin{abstract}
Abstrak
Pengadaan Barang/Jasa Pemerintah memiliki peran yang penting dalam mencapai tujuan bangsa Indonesia sebagaimana tercantum dalam Konstitusi. Terutama dalam pembangunan infrastruktur karena dengan adanya infrastruktur yang memadahi akan menggerakkan roda ekonomi lebih baik lagi dan pemerataan ekonomi di seluruh wilayah Indonesia. Pekerjaan konstruksi terintegrasi merupakan gabungan antara pekerjaan konstruksi dan jasa konsultansi. Setiap pelaksanaan konstruksi yang dilakukan oleh penyedia jasa harus mendapatkan pengawasan secara teknis dilapangan. Pengawasan lapangan harus dilakukan dengan menempatkan tenaga-tenaga ahli pengawas sesuai dengan kebutuhan dan kompleksitas pekerjaan. Dalam hal ini konsultan pengawas bertugas secara umum mengawasi pekerjaan konstruksi dengan tujuan agar terkendalinya proses penyelesaian pekerjaan dan meminimalisir penyimpangan yang terjadi dalam kontrak pengadaan. Metode pendekatan yang digunakan dalam penelitian ini adalah pendekatan perundang-undangan, pendekatan kasus, serta pendekatan konseptual untuk mengkaji permasalahan hukum yang terjadi, yaitu tanggung gugat konsultan pengawas dalam pekerjaan terintegrasi.

Kata Kunci: Pekerjaan Konstruksi Terintegrasi; Konsultan Pengawas; Kontrak Pengadaan Barang/Jasa.
\end{abstract}




\section{Pendahuluan}

Dalam pembukaan Undang-Undang Dasar Negara Republik Indonesia tahun 1945 termaktub di dalamnya cita-cita bangsa yakni yang melindungi segenap bangsa Indonesia dan seluruh tumpah darah Indonesia dan untuk memajukan kesejahteraan umum, mencerdaskan kehidupan bangsa, dan ikut melaksanakan ketertiban dunia yang berdasarkan kemerdekaan, perdamaian abadi dan keadilan sosial.Untuk mewujudkan salah satu cita - cita bangsa yakni memajukan kesejahteraan umum, pemerintah dituntut untuk menyediakan kebutuhan masyarakat dalam berbagai bentuk, baik berupa barang, jasa maupun pembangunan infrastruktur. Saat ini pemerintah Indonesia sedang menggalakkan pembangungan infrastruktur, karena dengan adanya infrastruktur yang memadahi akan menggerakkan roda ekonomi lebih baik lagi dan pemerataan ekonomi di seluruh wilayah Indonesia. Salah satu upaya pemerintah untuk meningkatkan pembangunan infrastruktur adalah dengan merealisasikan melalui mekanisme pengadaan barang/jasa pemerintah, karena dibutuhkan juga barang dan/jasa dalam jumlah besar untuk mewujudkannya.

Pengaturan pengadaan barang/jasa pemerintah terdapat pada Peraturan Presiden Nomor 16 Tahun 2018 yang mana pengertian pengadaan barang/jasa pemerintah dibatasi pada proses pengadaan yang dilakukan oleh Kementerian/ Lembaga/Perangkat daerah yang dibiayai oleh Anggaran Pendapatan dan Belanja Negara(APBN)/Anggaran Pendapatan dan Belanja Daerah (APBD), yang prosesnya dimulai identifikasi sampai serah terima hasil pekerjaan.

Pengadaan barang/jasa pemerintah dapat dilaksanakan melalui 2 (dua) cara, yakni dengan swakelola, dan/atau melalui penyedia. Pengadaan barang/jasa yang dilakukan dengan swakelola diperoleh dengan dikerjakan sendiri oleh Kementerian/ Lembaga/Perangkat Daerah, Kementerian/Lembaga/Perangkat Daerah lain, organisasi kemasyarakatan, atau kelompok masyarakat. Sedangkan pengadaan barang/jasa melalui penyedia diperoleh dengan cara disediakan oleh pelaku usaha.

Dalam hal pengadaan untuk pekerjaan konstruksi yang dilakukan oleh penyedia juga diatur pada Undang - Undang Nomor 2 Tahun 2017 Tentang Jasa Konstruksi (untuk selanjutnya disebut UUJK). Pengertian jasa konstruksi adalah 
layanan jasa konsultansi konstruksi dan/atau pekerjaan konstruksi. Dalam UUJK terdapat 3 (tiga) jenis usaha jasa konstruksi, antara lain:

1) Usaha jasa konsultansi konstruksi;

2) Usaha pekerjaan konstruksi; serta

3) Usaha pekerjaan konstruksi terintegrasi.

Pengertian untuk pekerjaan konstruksi dibatasi dalam hal keseluruhan atau sebagian kegiatan yang meliputi pembangunan, pengoperasian, pemeliharaan, pembongkaran, dan pembangunan kembali suatu bangunan. Dengan demikian dapat dikatakan bahwa pekerjaan konstruksi meliputi 3 (tiga) bidang pekerjaan, yakni perencanaan, pelaksanaan, serta pengawasan konstruksi.Pada prinsipnya, pelaksanaan masing - masing jenis pekerjaan ini harus dilakukan oleh penyedia jasa secara terpisah dalam suatu pekerjaan konstruksi, karena bertujuan untuk menghindari konflik kepentingan. ${ }^{1}$ Hal tersebut juga terdapat dalam etika pengadaan barang/jasa pemerintah, dimana masing masing pekerjaan tersebut harus dilakukan oleh penyedia jasa terpisah, namun terdapat pengecualian untuk pelaksanaan pengadaan pekerjaan yang terintegrasi.

Untuk mengatur hubungan hukum antara pengguna jasa dengan penyedia jasa maka dibutuhkan suatu kontrak kerja konstruksi. Dalam pengadaan pekerjaan konstruksi sangat diperlukan adanya kontrak, karena dengan adanya kontrak akan meminimalisir kerugian dan sengketa yang mungkin saja terjadi, serta sebagai dokumen yang berisi hak dan kewajiban para pihak.Sehingga yang dimaksud kontrak kerja konstruksi (yang selanjutnya disebut kontrak) dalam hal pengadaan barang/jasa pemerintah adalah keseluruhan dokumen yang mengatur hubungan hukum antara Pejabat Pembuat Komitmen / PPK dengan Penyedia.

PPK memiliki peran penting dalam pengadaan barang/jasa pemerintah. Pada pengadaan pekerjaan konstruksi, PPK akan membuat kontrak di setiap tahapan, baik dalam tahapan perencanaan, pelaksanaan, pengawasan maupun pertanggung jawaban anggaran. Setiap pelaksanaan konstruksi yang dilakukan oleh penyedia jasa

${ }^{1}$ Y.Sogar Simamora, Hukum Kontrak : Prinsip-Prinsip Hukum Kontrak Pengadaan Barang dan Jasa Pemerintah di Indonesia (Laksbang PRESindo Surabaya 2017).[219]. 
harus mendapatkan pengawasan secara teknis dilapangan. Pengawasan lapangan harus dilakukan dengan menempatkan tenaga-tenaga ahli pengawas sesuai dengan kebutuhan dan kompleksitas pekerjaan. Dalam hal ini konsultan pengawas bertugas secara umum mengawasi pekerjaan konstruksi mulai dari mutu, biaya serta waktu kegiatan pelaksanaan dengan tujuan agar terkendalinya proses penyelesaian pekerjaan dan meminimalisir penyimpangan yang terjadi dalam kontrak pengadaan.

Pada Perpres No.16/2018 terdapat etika pengadaan barang/jasa, salah satunya adalah menghindari dan mencegah terjadinya pertentangan kepentingan pihak yang terkait, baik secara langsung maupun tidak langsung, yang berakibat persaingan usaha tidak sehat dalam pengadaan barang/jasa. Pertentangan kepentingan pihak yang dimaksud salah satunya adalah mengenai konsultan perencana/pengawas dalam pekerjaan konstruksi bertindak sebagai pelaksana pekerjaan konstruksi yang direncanakannya/diawasinya, kecuali dalam pelaksanaan pengadaan pekerjaan terintegrasi. Yang dimaksud dengan Pekerjaan konstruksi terintegrasi merupakan gabungan antara pekerjaan konstruksi dan jasa konsultansi. Klasifikasi usaha pekerjaan konstruksi terintegrasi meliputi bangunan gedung dan bangunan sipil dengan layanan usaha yang dapat diberikan berupa rancang bangun (Design And Build), serta perekayasaan,pengadaan dan pelaksanaan (EngineeringProcurement-Construction).

Pada saat ini pemerintah sedang mempriortaskan pembangunan dengan cara mempercepat pembangunan insfrastruktur untuk mewujudkan kesejahteraan masyarakat yang merata, maka pemerintah melibatkan Badan Usaha Milik Negara (BUMN) dan Badan Usaha Milik Daerah (BUMD) dalam pelaksanaan proyek strategis nasional ${ }^{2}$ melalui penugasan pemerintah. BUMD ditugaskan untuk melaksanakan proyek strategis nasional dalam pelaksanaan pembangunan daerah. BUMN/BUMD dalam penugasannya mendapat kekhususan yakni BUMN/BUMD

\footnotetext{
${ }^{2}$ Proyek strategis nasional adalah proyek yang dilaksanakan oleh Pemerintah, Pemerintah Daerah, dan/atau Badan Usaha yang memiliki sifat strategis untuk meningkatkan pertumbuhan dan pemerataan pembangunan dalam rangka meningkatkan kesejahteraan masyarakat dan pembangunan daerah.
} 
penerima penugasan dimungkinkan untuk menunjuk langsung BUMN/BUMD lain atau anak perusahaan BUMN/BUMD sebagai pelaksana jasa konstruksi dalam pembangunan yang ditugaskan kepadanya. Namun penunjukan tersebut hanya untuk pekerjaan terintegrasi.

\section{Para Pihak Dalam Kontrak Jasa Konstruksi Terintegrasi}

Para pihak dalam pengadaan barang jasa pemerintah diatur dalam Peraturan Presiden No.16 Tahun 2018 serta Permen PUPR No.7 Tahun 2019, kontrak kerja konstruksi adalah keseluruhan dokumen yang mengatur hubungan hukum natara Pejabat Pembuat Komitmen (yang selanjutnya disebut PPK) dengan Penyedia. Dalam pengikatan hubungan kerja tersebut harus dilakukan berdasarkan prinsip persaingan yang sehat. PPK merupakan wakil dari pemerintah karena sumber pembiayaan pekerjaan konstruksi menggunakan APBN/APBD.

Melihat ketentuan dari Pasal 39 UUJK, secara umum para pihak dalam kontrak jasa konstruksi terdiri dari Pengguna Jasa dan Penyedia Jasa. Pengertian Pengguna Jasa dalam UUJK adalah orang perseorangan atau badan yang merupakan pemilik atau pemberi pekerjaan yang menggunakan layanan Jasa Konstruksi. Pengguna Jasa adalah pihak yang mempunyai modal yang nantinya akan melimpahkan pekerjaannya kepada penyedia jasa. Pengguna jasa juga biasa disebut dengan Pemilik Pekerjaan atau owner. Sedangkan pengertian Penyedia Jasa adalah orang perseorangan atau badan pemberi layanan Jasa Konstruksi. Penyedia dapat juga disebut sebagai kontraktor ataupun konsultan konstruksi.

Untuk usaha orang perseorangan dan badan usaha yang terkualifikasi kecil hanya dapat menyelenggarakan jasa konstruksi yang:

1. Berisiko kecil;

2. Berteknologi sederhana; dan

3. Berbiaya kecil.

Sedangkan untuk badan usaha jasa konstruksi yang terkualifikasi besar dan berbadan hukum, perwakilan usaha jasa konstruksi asing hanya dapat menyelenggarakan jasa konstruksi yang: 
1. Berisiko besar;

2. Berteknologi tinggi; dan

3. Berbiaya besar.

Jasa konstruksi selain dibutuhkan dalam sektor privat juga dibutuhkan dalam sektor publik. Untuk sektor publik jasa konstruksi dilakukan untuk melakukan kegiatan pemerintah dengan melalui mekanisme pengadaan barang/jasa pemerintah karena bertujuan untuk memajukan kesejahteraan umum, dan pemerataan perekonomian di Indonesia. Misalnya pengadaan barang/jasa pemerintah dalam pekerjaan konstruksi adalah pembangunan infrastruktur jalan tol, pembangunan bendungan, pembangunan Pembangkit Listrik Tenaga Air/Uap/Nuklir (PLTA/ PLTU/PLTN). Sedangkan untuk sektor privat jasa konstruksi digunakan untuk pembangunan apartemen, pusat perbelanjaan/mall, pabrik.

Pekerjaan konstruksi yang dilakukan dalam rangka kegiatan pemerintah melalui mekanisme pengadaan barang/jasa pemerintah tergolong pada jenis kontrak yang bersifat pembelanjaan. ${ }^{3}$ Kontrak pengadaan barang/jasa pemerintah pada dasarnya merupakan kontrak komersial, namun tidak sepenuhnya bebas dalam mengatur hubungan hukum atau mengatur kewajiban kontraktualnya seperti kontrak komersial pada umumnya. Karena dalam kontrak pengadaan barang/jasa terdapat unsur hukum publik didalamnya. Sumber pembiayaan dalam kontrak pengadaan pada umunya berasal dari keuangan negara dalam hal ini APBN/APBD, disamping dana yang berasal dari pinjaman/hibah luar negeri (PHLN). ${ }^{4}$ Pada dasarnya prinsip yang berlaku bagi kontrak privat pada umunya juga berlaku pada kontrak atau perjanjian pengadaan barang/jasa. Sehingga kontrak pengadaan barang/jasa harus sesuai dengan prinsip dan aturan tentang hukum perikatan pada Bab I sampai dengan Bab IV Buku III BW. Tetapi karena adanya faktor kepentingan umum dan terlibatnya anggaran negara membuat kontrak pemerintah tunduk pada batasanbatasan tertentu baik yang terdapat dalam konstitusi maupun undang-undang. ${ }^{5}$

\footnotetext{
${ }^{3}$ Y.Sogar Simamora, Op.Cit.[2].

${ }^{4}$ ibid.[5].

${ }^{5}$ ibid. [14].
} 


\section{Hubungan Hukum Para Pihak Dalam Kontrak Jasa Konstruksi Terintegrasi}

Hubungan hukum jasa konstruksi lahir karena adanya perjanjian konstruksi sebagai landasan kontraktualnya. ${ }^{6}$ Definisi pekerjaan konstruksi terdapat dalam Pasal 1 Angka 3 UUJK, dimana yang dimaksud pekerjaan konstruksi adalah keseluruhan atau sebagian kegiatan yang meliputi pembangunan, pengoperasian, pemeliharaan, pembongkaran, dan pembangunan kembali suatu bangunan.

Hubungan hukum dalam kontrak pengadaan barang jasa pemerintah diatur dalam Peraturan Menteri PUPR No.7 Tahun 2019, dimana yang dimaksud dengan kontrak kerja konstruksi adalah keseluruhan dokumen yang mengatur hubungan hukum antara Pejabat Pembuat Komitmen (PPK) dengan Penyedia. Hubungan hukum dalam jasa konstruksi selain tunduk pada kontrak yang telah dibuat, juga harus tunduk pada ketentuan perundang - undangan yang berlaku.

Hubungan hukum para pihak dalam kontrak rancang bangun.

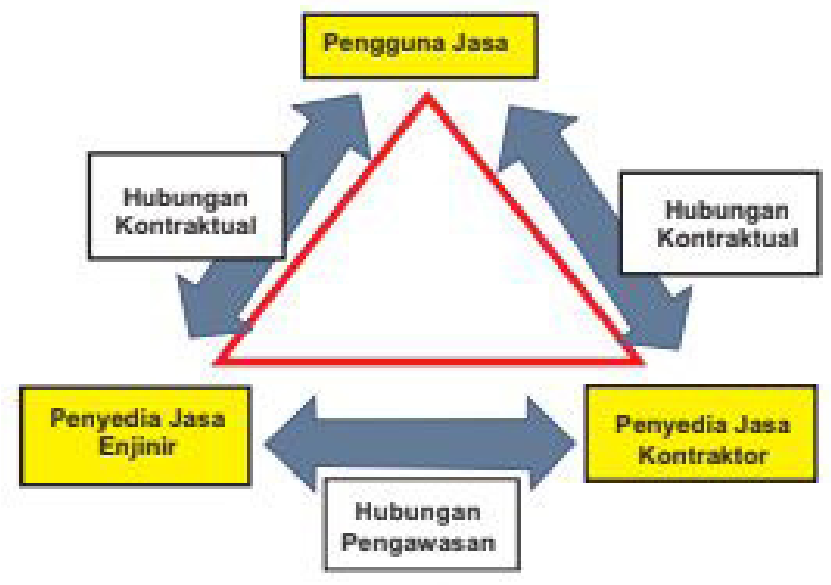

\section{Jenis Kontrak Konstruksi}

Jenis kontrak kerja kosntruksi di Indonesia tedapat beberapa versi yaitu:

a. Versi dari Pemerintah, biasanya standar yang dipakai adalah standar yang dikeluarkan oleh Kementerian PUPR.

b. Versi Swasta Nasional, dalam versi ini disesuaikan dengan keiinginan Pengguna Jasa/Pemilik Proyek. Dapat dibuat dengan mengikuti standar Pemerintah atau

${ }^{6}$ Y.Sogar Simamora, dkk., Buku Ajar Hukum Kontrak (Yuridika 2012).[160]. 
mengikuti sistem kontrak luar negeri sepertu FIDIC (Federation Internationale des Ingenieurs Counsels atau International Federation of Consulting Engineers), JCT (Joint Contract Tribunals) atau AIA (American Institute of Architects).

c. Versi/Standar Swasta/Asing.

Umumnya menggunakan FIDIC atau JCT.

Dahulu kontrak konstruksi hanya terdapat satu jenis saja, yakni kontak konstruksi konvensional. Dalam tipe kontrak konvensional dilakukan untuk pembangunan gedung atau proyek yang tidak terlalu kompleks. Pada kontrak konstruksi konvensional terdapat pemisahan antara kontrak kerja konstruksi yang dibagi sesuai dengan tahapan dalam pekerjaan konstruksi, yakni terdiri dari :

1. Kontrak kerja konstruksi untuk perencanaan;

2. kontrak kerja konstruksi pelaksanaan; dan

3. kontrak kerja konstruksi untuk pengawasan.

Kontrak kerja konstruksi untuk perencanaan adalah kontrak antara pengguna jasa dan penyedia jasa dalam hal ini penyedia adalah konsultan perencana untuk merencanakan proyek, yang meliputi rangkaian kegiatan mulai dari studi pengembangan sampai dengan penyusunan dokumen kontrak kerja konstruksi. Yang kedua adalah kontrak kerja konstruksi pelaksanaan, dimana kontrak tersebut adalah perjanjian antara pengguna jasa dan penyedia jasa yang mengerjakan proyek, penyedia memberikan layanan jasa pelaksanaan pekerjaan konstruksi mulai dari penyiapan lapangan dampai dengan penyerahan akhir hasil pekerjaan konstruksi. Kemudian kontrak kerja konstuksi untuk pengawasan adalah kontrak antara pengguna jasa dengan konsultan pengawas sebagai penyedia jasa untuk mengawasi jalannya proyek.

Kontrak kerja konstruksi berdasarkan Peraturan Pemerintah No.29 Tahun 2000 dibedakan atas bentuk imbalan, jangka waktu pelaksanaan pekerjaan, sertacara pembayaran hasil pekerjaan.

1. Berdasarkan bentuk imbalan yang terdiri dari :

a. Lump Sum 

b. Harga Satuan
c. Biaya Tambah Imbalan Jasa
d. Gabungan Lump Sum dan Harga Satuan
e. Aliansi,

2. Berdasarkan jangka waktunya pelaksanaan pekerjaan konstruksi yang terdiri dari:
a. Tahun tunggal
b. Tahun jamak

3. Berdasarkan cara pembayaran hasil pekerjaan :

a. Sesuai kemajuan pekerjaan

b. Secara berkala

Selain kontrak konvensional juga terdapat pula kontrak untuk pekerjaan konstruksi terintegrasi, yang dimaksud pekerjaan konstruksi terintegrasi adalah gabungan antara pekerjaan konstruksi dan jasa konsultansi, untuk kontrak pekerjaan terintegrasi dapat dituangkan dalam 1 (satu) kontrak kerja konstruksi. Contoh pekerjaan terintegrasi adalah rancang bangun (Design and Build), dan perekayasaan - pengadaan - pelaksanaan (Engineering Procurement Construction /EPC). Dalam kontrak rancang bangun, penyedia jasa memiliki tugas membuat suatu perencanaan proyek yang lengkap dan sekaligus melaksanakannya dalam satu kontrak konstruksi, jenis kontrak ini digunakan untuk pekerjaan konstruksi sipil/bagunan gedung. ${ }^{7}$ Sedangkan untuk kontrak EPC sesungguhnya adalah bentuk dari kontrak rancang bangun yang dimaksudkan untuk pembangunan pekerjaanpekerjaan dalam industri gas bumi, minyak, dan petrokimia. ${ }^{8}$ Sebagaimana diatur dalam Pasal 15 Ayat (2) UUJK mengenai layanan usaha pekerjaan konstruksi terintegrasi yang meliputi rancang bangun dan EPC. Untuk pekerjaan konstruksi rancang bangun diatur lebih lanjut di dalam Peraturan Menteri PUPR No. 12/ PRT/M/2017 tentang Standar dan Pedoman Pengadaan Pekerjaan Konstruksi Terintegrasi Rancang dan Bangun. Sedangkan untuk EPC belum ada peraturan menteri PU yang khusus mengatur mengenai EPC.

${ }^{7}$ I Gusti Agung Ayu Lestari, 'Perbandingan Kontrak Konstruksi Indonesia Dengan Kontrak Konstruksi Internasional' (2013) Vol 7 No 22013 Jurnal Ganec Swara.[66].

${ }^{8}$ ibid. 


\section{Kontrak Konstruksi Terintegrasi Menurut FIDIC}

FIDIC merupakan singkatan dari Federation Internationale Des Ingenieurs Conseils (International Federation of Consulting Engineers) yang berkedudukan di Lausanne, Swiss. FIDIC didirikan pada tahun 1913 oleh Perancis, Belgia dan Swiss. Pada tahun 1999 FIDIC menerbitkan seri pelangi atau rainbow series persyaratan umum kontrak, yang terdiri dari:

1. Condition of Contract for Construction (Red Book), atau dikenal dengan buku merah untuk konstruksi. Red Book telah mengalami beberapa kali perubahan, edisi pertamanya diterbitkan dan digunakan pada tahun 1957 dengan nama Conditions of Contract (International) for Works of Civil Engineering Construction. ${ }^{9}$ Terakhir kali revisi pada tahun 1999 dan 2006, dalam edisi 2006 dijadikan varian kontrak tersendiri dengan judul Construction Contract $M D B$ Harmonised. Syarat-syarat dalam buku merah ini digunakan untuk pembangunan atau perancanaan pekerjaan yang didesain oleh pemilik pekerjaan ataupun oleh engineer. Sehingga dalam konsep buku merah ini Kontraktor melakukan pekerjaan yang sebelumnya telah didesain oleh engineer.

2. Conditions of Contract for Plant and Design-Build (Yellow Book), dikenal dalam Bahasa Indonesia sebagai buku kuning, untuk Instalasi Mesin dan Rancang Bangun. Syarat - syarat kontrak pada yellow book dipergunakan untuk pelaksanaan pembangunan instalasi mekanikal dan instalasi elektrikal maupun juga untuk desain dan pelaksanaan konstruksi bangunan dan pekerjaan engineering. Design and Build melakukan pembayaran per termin sesuai kemajuan pekerjaan. Dalam aspek pengawasan, untuk design and build pemilik proyek dapat melakukan pengawasan dari tahap awal sampai akhir pekerjaan. Engineer bukan merupakan suatu entitas dengan pemberi kerja, namun merupakan entitas lain yang membantu pemberi kerja dalam pengawasan pelaksanaan pekerjaan yang dikerjakan oleh kontraktor. Peran engineer yang ada pada yellow book adalah dimana setiap pelaksanaan pekerjaan perlu persetujuan dari engineer.

3. Conditions of Contract EPC/Turnkey Projects (Silver Book), dalam Bahasa Indonesia dikenal sebagai buku perak untuk EPC / Proyek Turnkey. Silver book memiliki persamaan dengan yellow book yaitu desain dan pembangunan dilakukan oleh Kontraktor. Dalam silver book kontraktor bertanggung jawab atas segala kewajiban perencanaan dan pelaksanaan proyek. Kontraktor juga akan menerima tanggung jawab penuh dan melakukan seluruh proses pekerjaan konstruksi mulai dari perencanaan, pengadaan barang dan material, serta pelaksanaan konstruksi. Kontraktor dalam silver book dianggap telah mendapatkan semua informasi yang diperlukan tentang risiko, kemungkinan

${ }^{9}$ Jeremy Glover, FIDIC and Overview : The Latest Developments, Comparasions, Claims and a Look Into The Future (Fenwick Elliot 2008).[1]. 
dan keadaan lain yang dapat mempengaruhi dan berdampak pada pekerjaan. Biasanya pekerjaan yang menggunakan kontrak semacam ini adalah pekerjaan yang memiliki kerumitan serta resiko yang tinggi, misalnya untuk pekerjaan industri minyak, gas bumi, dan petrokimia. Untuk aspek pengawasan dalam kontrak EPC, pemilik proyek mengawasi jalannya pekerjaan mulai dari tahap awal pekerjaan sampai dengan selesainya pekerjaan. Pembayaran dalam Turnkey dilakukan sekaligus setalah selesai pekerjaan.

4. Short Form of Contract (Green Book), untuk proyek - proyek kecil dan tidak kompleks dikenal sebagai buku hijau. Kontrak ini dipergunakan pada proyek dimana desain pekerjaan dibuat oleh pemilik pekerjaan atau dapat juga dibuat oleh kontraktor.

\section{Kontrak Konstruksi Rancang Bangun (Design And Build)}

Pekerjaan konstruksi rancang bangun dalam penjelasan Pasal 15 Ayat (2) huruf a UUJK menunjukkan integrasi penyediaan jasa antara pekerjaan konstruksi dengan konsultansi konstruksi yang mencakup seluruh aspek penyelenggaraan jasa konstruksi, tetapi tidak mencakup proses pengadaan. Beberapa peraturan perundang-undangan yang mengatur mengenai ketentuan terkait pekerjaan konstruksi terintegrasi rancang bangun, yaitu:

1. Undang - Undang Nomor 2 Tahun 2017 Tentang Jasa Konstruksi.

Di dalam UUJK tidak diatur secara detail mengenai pengadaan pekerjaan terintegrasi rancang bangun, namun di dalam Pasal 18 UUJK telah dinyatakan untuk ketentuan lebih lanjut mengenai jenis, sifat, klasifikasi, layanan usaha, perubahan atas klasifikasi dan layanan usaha, dan usaha rantai pasok sumber daya konstruksi sebagaimana dimaksud dalam Pasal 11 sampai dengan Pasal 17 UUJK diatur dalam Peraturan Pemerintah.

2. Peraturan Pemerintah Nomor 29 tahun 2000 Tentang Penyelenggaraan Jasa Konstruksi sebagaimana Telah Diubah Terakhir Dengan Peraturan Pemerintah Nomor 54 Tahun 2016.

Dalam Peraturan Pemerintah Nomor 29 Tahun 2000 tentang Penyelenggaraan Jasa Konstruksi (selanjutnya disebut PP No.29 Tahun 2000) pengaturan mengenai pekerjaan jasa konstruksi terintegrasi tercantum di Pasal 13. Di dalam Pasal 13 PP No.29 tahun 2000 terdapat kriteria untuk pekerjaann 
yang dapat dilakukan dengan layanan jasa konstruksi secara terintegrasi, antara lain pekerjaan yang :

a. Bersifat kompleks;

b. Memerlukan teknologi tinggi;

c. Mempunyai risiko tinggi; dan

d. Memiliki biaya besar.

Kemudian PP No. 29 tahun 2000 mengalami perubahan pertama dengan adanya Peraturan Pemerintah Nomor 59 Tahun 2010 (selanjutnya disebut PP No.59 Tahun 2010). PP No. 59 Tahun 2010 mengubah ketentuan dari pasal 13 ayat (3) huruf a dan ayat (4) PP No.29 Tahun 2000.

Pada tahun 2015 terjadi perubahan kedua atas PP No.29 Tahun 2000, yakni dengan berlakunya Peraturan Pemerintah Nomor 79 Tahun 2015 (selanjutnya disebut PP No.79 Tahun 2015). Dalam PP No.79 Tahun 2015 ini disisipkan antara ketentuan Pasal 13 dengan Pasal 14 dalam PP No.29 Tahun 2000, yakni Pasal 13A. Pasal 13 A menyatakan untuk pekerjaan jasa terintegrasi, Badan Usaha Milik Negara (BUMN) yang mendapat penugasan dari Pemerintah dapat melaksanakan penunjukan langsung kepada BUMN lain atau anak perusahaan BUMN.

Selanjutnya PP No. 29 Tahun 2000 mengalami perubahan ketiga dengan diundangkannya Peraturan Pemerintah Nomor 54 Tahun 2016 (untuk selanjutnya disebut PP No. 54 Tahun 2016). Berkaitan dengan pekerjaan konstruksi terintegrasi PP No.54 Tahun 2016 mengubah ketentuan pasal 13A PP No.79 Tahun 2015. Di dalam Pasal 13A PP 54 Tahun 2016 terdapat penambahan pengaturan mengenai Badan Usaha Milik Daerah (BUMD) yang mendapat penugasan dari pemerintah daerah dapat melaksanakan penunjukan langsung kepada BUMD lain, BUMN, dan/atau anak perusahaan BUMN untuk pekerjaan terintegrasi.

3. Peraturan Presiden Nomor 16 Tahun 2018 Tentang Pengadaann Barang/Jasa Pemerintah.

Dengan adanya Peraturan Presiden Nomor 16 Tahun 2018 (yang selanjutnya disebut Perpres No.16 Tahun 2016), maka Peraturan Presiden 
Nomor 54 Tahun 2000 tentang Pengadaan Barang/Jasa Pemerintah yang telah diubah beberapa kali, dicabut dan dinyatakan tidak berlaku. Melihat ketentuan dalam Pasal 93 Perpres No.16 Tahun 2018, bahwa pada saat Perpres No,16 Tahun 2018 mulai berlaku, semua peraturan pelaksanaan dari Perpres No.54 Tahun 2000 dan perubahannya dinyatakan masih tetap berlaku sepanjang tidak bertentangan dengan ketentuan dalam Perpres No.16 Tahun 2018Pengadaan barang jasa berdasarkan Pasal 3 Ayat (1) Perpres No.16 Tahun 2016 meliputi:

1) Barang;

2) Pekerjaan Konstruksi;

3) Jasa Konsultansi; dan

4) Jasa Lainnya.

Selanjutnya pada Pasal 3 Ayat (2) menyatakan jika pengadaan barang/jasa tersbut dapat dilakukan secara terintegrasi.. Pada penjelasan Pasal 54 ayat (2) Peraturan Presiden Nomor 54 Tahun 2000, kontrak Rancang Bangun dinyatakan sebagai salah satu model kontrak pengadaan terintegrasi.

4. Peraturan Menteri Pekerjaan Umum dan Perumahan Rakyat Nomor 12/ PRT/M/2017 tentang Standar dan Pedoman Pengadaan Pekerjaan Konstruksi Terintegrasi Rancang dan Bangun (Design and Build).

Pengertian pekerjaan konstruksi terintegrasi rancang bangun (Design and Build) dalam Permen PUPR No.12 Tahun 2017 tercantum dalam Pasal 1 Angka 12, yakni seluruh pekerjaan yang berhubungan dengan pembangunan suatu bangunan atau pembuatan wujud fisik lainnya, dimana pekerjaan perancangan terintegrasi dengan pelaksanaan konstruksi. Permen PUPR No.12 Tahun 2017 ini ditujukan untuk pelaksanaan pengadaan pekerjaan konstruksi rancang bangun yang pembiayaannya dari APBN/APBD. Pihak yang terkait dalam kontrak pekerjaan konstruksi terintegrasi rancang bangun sesuai dengan ketentuan Permen PUPR No.12 Tahun 2017 adalah PPK dengan penyedia. PPK sebagai wakil dari pemerintah karena sumber pembiayaan pekerjaan konstruksi rancang bangun menggunakan APBN/ABPD.

Pekerjaan konstruksi terintegrasi rancang bangun harus memenuhi beberapa kriteria yang diatur dalam Pasal 5 Permen PUPR No.12 Tahun 2017, yaitu: 
1. pekerjaan kompleks, atau

2. pekerjaan tertentu.

Yang dimaksud pekerjaan kompleks adalah pekerjaan yang memerlukan teknologi tinggi, mempunyai resiko tinggi, menggunakan peralatan yang di desain khusus, serta pekerjaan yang bernilai di atas Rp100.000.000.000,00 (seratus miliar rupiah). Pekerjaan kompleks dengan dana APBN ditetapkan oleh Menteri/Kepala Kementerian/ Lembaga/ Institusi dan dengan sumber dana APBD ditetapkan oleh Gubernur/Walikota/Bupati pada Pemerintah Daerah.

Sedangkan yang dimaksud dengan pekerjaan tertentu adalah pekerjaan yang mendesak untuk segera dimanfaatkan. Pekerjaan kompleks dengan dana APBN ditetapkan oleh Menteri/Kepala Kementerian/ Lembaga/ Institusi dan dengan sumber dana APBD ditetapkan oleh Gubernur/Walikota/Bupati pada Pemerintah Daerah. Dalam hal kontrak pekerjaan konstruksi rancang bangun yang bernilai di atas 100 (seratus) miliar rupiah harus memperoleh pendapat dari Ahli Hukum Kontrak sebelum kontrak ditandatangani oleh para pihak.

Pada kontrak rancang bangun terdapat resiko tinggi yang harus ditanggung oleh Penyedia Jasa, sehingga jika terjadi perbedaan antara pelaksanaan dengan desain dan gambar di lapangan menjadi tanggung jawab penyedia jasa. Oleh karena itu pada kontrak rancang bangun lebih tepat untuk digunakan kontrak Lump sum.

Kelebihan dari kontrak rancang bangun adalah pekerjaan konstruksi dapat berlangsung dengan lebih operasional, efektid dan efisien. Layanan design and build akan memotong jalur birokrasi dan komunikasi antara perencana dengan pelaksana, sehingga menghemat waktu dan biaya.

\section{Kontrak Konstruksi Engineering Procurement Construction (EPC)}

Pada perkembangannya dalam kontrak kosntruksi terintegrasi adalah dengan adanya suatu bentuk model kontrak yang diperuntukkan pada proyek-proyek minyak dan gas serta pembangkit listrik, yakni kontrak EPC. Pada kontrak EPC terdapat 
tiga kegiatan yakni Perekayasaan (Engineering), Pengadaan (Procurement), dan Konstruksi (Construction), yang tidak terpisah dan menjadi tanggung jawab dari satu penyedia.

Kontrak EPC dilatarbelakangi oleh standar kontrak yang diterbitkan oleh FIDIC. Dokumen FIDIC yang digunakan sebagai acuan dari proyek EPC adalah silver book atau FIDIC untuk proyek EPC/Turnkey. Di Indonesia dokumen FIDIC digunakan pada proyek yang dibiayai oleh dana luar negeri atau yang bekerja sama dengan kontraktor asing. Konsep EPC/Turnkey Contract digunakan dalam hal segala kewajiban dan tanggung jawab perencanaan dan pelaksanaann proyek akan menjadi tanggung jawab kontraktor. Melihat konsep tersebut, kontraktor akan melaksanakan seluruh proses pekerjaan mulai dari perencanaan, pengadaan barang dan material dan pelaksanaan konstruksi. Setelah seluruh bangunan dan fasilitas yang dibutuhkan selesai dan bekerja dengan baik serta siap untuk dioperasikan disebut turn of the key.

Di Indonesia belum ada peraturan pelaksana pembentukan dan penyusunan yang secara khusus mengatur mengenai Kontrak EPC ini. Namun pada penjelasan Pasal 46 ayat (2) UUJK menyatakan, bahwa:

"Kontrak kerja konstruksi dapat mengikuti perkembangan kebutuhan utuk mengakomodasi bentuk-bentuk kontrak kerja konstruksi yang berkembang di masyarakat. Bentuk kontrak mengikuti delivery system penyelenggaraan konstruksi yaitu antara lain : rancang-penawaran-bangun (design bid build); rancang-bangun (design build); perekayasaan-pengadaan-pelaksanaan (engineering procurement construction); manajemen konstruksi dan kemitraan. Selain delivery system, bentuk kontrak juga mengikuti sisterm pe0mbayaran dan sistem perhitungan hasil pekerjaan. Sistem pembayaran jasa mencakup antara lain : di muka, progress, milestone, dan turnkey. Sedangkan sistem perhitungan hasil pekerjaan mencakup antara lain : lumpsum, harga satuan, gabungan harga lumpsum dan harga satuan, presentase nila, cost reimbursable, dan target cost".

Melihat penjelasan dari pasal 46 ayat (2) UUJK terebut dinyatakan bahwa pembentukan dan penyusunan kontrak konstruksi terintegrasi mengikuti delivery system, artinya mekanisme penyusunan kontrak berdasarkan peraturan 
di setiap kementerian. ${ }^{10}$ Meskipun kontrak EPC belum diatur oleh Peraturan Menteri PUPR, namun dalam Peraturan Menteri Energi Sumber Daya Mineral Nomor 27 Tahun 2008 Tentang Kegiatan Usaha Penunjang Minyak dan Gas Bumi (selanjutnya disebut Permen ESDM No.27 Tahun 2008) mengatur mengenai EPC, karena pada bidang usaha jasa konstruksi minyak dan gas salah satunya menggunakan EPC. Yang dimaksud dengan usaha jasa konstruksi migas sendiri pengaturannya terdapat dalam Pasal 1 angka 5 Permen ESDM No.27 Tahun 2008, yakni kegiatan usaha jasa layanan untuk penanganan pekerjaan bangunan atau konstruksi atau wujud fisik lainnya dalam menunjang kegiatan usaha minyak dan gas bumi.

\section{Hak Dan Kewajiban Para Pihak Pada Kontrak Konstruksi Terintegrasi}

Dalam kontrak pengadaan pengguna jasa terintegrasi memiliki kewajiban untuk membayar biaya pekerjaan konstruksi yang didukung oleh dokumen pembuktian dari lembaga keuangan bukan bank. Metode pembayaran yang dilakukan oleh pengguna jasa dilakukan sesuai dengan jenis kontraknya. Kewajiban dari penyedia jasa adalah melaksanakan pekerjaan sesuai dengan syarat dan ketentuan yang ada di dalam kontrak. Penyedia bertanggung jawab atas terpenuhinya spesifikasi sesuai dengan jadwal yang ditentukan termasuk atas resiko yang mungkin terjadi dalam pelaksanaan pekerjaan. ${ }^{11}$ Kontraktor juga wajib untuk memberikan informasi dan melaporkan progres pelaksanaan pekerjaan dan memberikan keterangan kapada pengguna jasa dalam ssetiap periode yang ada di dalam kontrak yang telah disepakati bersama.

\section{Metode Pemilihan Konsultan Pengawas}

Konsultan pengawas merupakan jasa layanan profesional yang diberi tugas oleh pemilik proyek untuk mengawasi seluruh proses konstruksi dengan cermat secara

\footnotetext{
${ }^{10}$ Dwi Mariyati, 'Prinsip Hukum Dalam Penyusunan Dan Pelaksanaan Kontrak Engineering Procurement Constuction (Kontrak “EPC”)' (2018) 33 Yuridika.[197].

${ }^{11}$ ibid.[257].
} 
obyektif pada tahap pelaksanaan sampai selesainya konstruksi. ${ }^{12}$ Konsultan pengawas dapat berupa badan usaha ataupun perorangan. Untuk dapat menjadi konsultan pengawas diperlukan sumber daya manusia yang ahli dibidang masing-masing seperti teknik sipil, arsitektur, mekanikal elektrikal, listrik dan lain-lain sehingga sebuah bangunan dapat dibangun dengan baik dalam waktu cepat dan efisien. Berdasarkan UUJK konsultan pengawas masuk kedalam Jasa konsultansi konstruksi. Layanan yang diberikan jasa konsultansi konstruksi meliputi pengkajian, perencanaan, perancangan, pengawasan, dan/ atau manajemen penyelenggaraan konstruksi. Menurut PP No. 28 Tahun 2000 layanan pengawasan jasa konstruksi meliputi pengawasan pekerjaan konstruksi, pengawasan keyakinan mutu dan ketepatan waktu, dan proses perusahaan dari hasil pekerjaan konstruksi. Metode pemilihan penyedia jasa konsultansi dapat dilakukan melalui Penunjukan langsung atau dengan seleksi. Kriteria untuk menjadi konsultan pengawas terdapat dalam Peraturan Lembaga Pengembangan Jasa Konstruksi Nasional Nomor 4 Tahun 2017 Tentang Sertifikasi dan Registrasi Usaha Jasa Perencana Dan Pengawas Konstruksi, yang mana usaha jasa perencana dan pengawas konstruksi dapat berbentuk perorangan atau badan usaha baik badan usaha nasional maupun badan usaha asing. Klasifikasi untuk badan usaha jasa pengawas konstruksi meliputi: pengawasan arsitektur; pengawasaran rekayasa (engineering); pengawasan penataan ruang. Badan usaha tersebut berlatar belakang sipil, arsitektur, elektrikal, tata lingkungan, manajemen pelaksanaan. Namun dalam pasal 12 peraturan LPJK tersebut dinyatakan jika badan usaha jasa perencanaan dan pengawasan konstruksi tidak diperbolehlan untuk mengambil jasa pelaksanaan konstruksi dan/ atau jasa konstruksi terintegrasi.

\section{Kekhususan Badan Usaha Milik Negara (BUMN) Dalam Kontrak Pekerjaan Jasa Konstruksi Terintegrasi}

Peraturan Pemerintah Nomor 79 Tahun 2015 yang merupakan perubahan

\footnotetext{
${ }^{12}$ Nurcawenda R., Riyadi., 'Kajian Pengaruh Peranan Konsultan Pengawas Terhadap Pelaksanaan Proyek Pembangunan Pendopo Di Karawang Jawa Barat'(2018) 13 ISU TEKNOLOGI STT MANDALA.[61].
} 
kedua atas Peraturan Pemerintah Nomor 29 Tahun 2000 Tentang Penyelenggaraan Jasa Konstruksi, BUMN yang mendapatkan penugasan dari pemerintah dan dapat melakukan penunjukan langsung kepada BUMN lain atau anak perusahaan BUMN, pengaturannya ada di dalam Pasal 13A Peraturan Pemerintah Nomor 79 Tahun 2015. Selanjutnya pada Peraturan Pemerintah Nomor 54 Tahun 2016 yang merupakan perubahan ketiga atas Peraturan Pemerintah Nomor 29 Tahun 2000, dalam perubahan Pasal 13A dinyatakan tidak hanya BUMN saja yang dapat melakukan penunjukan langsung kepada BUMN lain atau anak perusahaan BUMN dalam pekerjaan terintegrasi, namun Badan Usaha Milik Daerah (selanjutnya disebut BUMD) yang mendapatkan penugasan dari pemerintah juga dapat melakukan penunjukan langsung kepada BUMD lain, anak perusahaan BUMD, BUMN, dan/ atau anak perusahaan BUMN.

\section{Organ Pengadaan Dalam Kontrak Konstruksi Terintegrasi}

Secara umum peraturan terkait pengadaan jasa konstruksi pemerintah ada di dalam Perpres No.16 Tahun 2018 yang mencabut Perpres No. 54 Tahun 2010. Organ pengadaan terdiri dari PA, KPA, PPK, Pejabat Pengadaan, PPHP, dan Penyedia. Untuk pekerjaan konstruksi rancang bangun organ pelaksanaannya diatur dalam Permen PUPR No.12 Tahun 2017 Pasal 32, yang terdiri dari:

1) $\mathrm{PA} / \mathrm{KPA}$;

2) PPK;

3) Direksi Lapangan;

4) Tim Teknis/ konsultan manajemen konstruksi;

5) Panitia peneliti pelaksanaan kontrak;

6) PPHP;

7) Unit perancang;

8) Unit pelaksanaan proyek; dan

9) Unit pengendali mutu.

\section{Fungsi Dan Tanggung Gugat Konsultan Pengawas Pada Kontrak Konstruksi Terintegrasi}

Tanggung gugat adalah suatu rangkaian untuk menanggung kerugian yang diakibatkan karena kesalahan atau resiko.Tanggung gugat konsultan pengawas 
adalah jika terjadi kegagalan bangunan yang disebabkan karena kesalahan dari perencana atau konsultan pengawas dan terbukti menimbulkan kerugian kepada pihak lain, maka perencana atau pengawas konstruksi wajib bertanggung jawab sesuai bidang profesi dan dikenakan ganti rugi. Upaya perlindungan hukum terhadap masyarakat atas perbuatan yang merugikan masyarakat berkaitan dengan jasa konstruksi (kegagalan bangunan ${ }^{13}$ ) UUJK mengatur mengenai hal tersebut khususnya dengan subyek hukum penyedia jasa, antara lain:

Pasal 60 ayat (1):

"Dalam hal penyelenggaraan Jasa Konstruksi tidak memenuhi Standar Keamanan, Keselamatan, Kesehatan, dan Keberlanjutan sebagaimana dimaksud dalam Pasal 59, Pengguna Jasa dan/atau Penyedia Jasa dapat menjadi pihak yang bertanggung jawab terhadap Kegagalan Bangunan”.

Pasal 67 ayat (1):

"Penyedia jasa dan/atau pengguna jasa wajib memberikan ganti kerugian jika terjadi kegagalan bangunan".

Sedangkan defisini kegagalan pekerjaan konstruksi diatur dalam Pasal 31 PP No.29

Tahun 2000 , yakni :

"Kegagalan pekerjaan konstruksi adalah keadaan hasil pekerjaan konstruksi yang tidak sesuai dengan spesifikasi pekerjaan sebagaimana disepakati dalam kontrsak kerja konstruksi baik sebagian maupun keseluruhan akibat kesalahan pengguna jasa maupun penyedia jasa".

Adapun tanggung jawab atas kegagalan bangunan yang diatur dalam Permen PUPR No.12 Tahun 2017 yang berkaitan dengan pekerjaan terintegrasi Rancang Bangun, yaitu:

Pasal 45:

"Kegagalan bangunan merupakan tanggung jawab pengguna jasa dan/atau penyedia jasa sesuai dengan ketentuan peraturan perundang-undangan".

Pasal 46:

"Kewajiban pertanggungan terhadap kegagalan bangunan terhitung sejak tanggal penyerahan akhir pekerjaan".

\footnotetext{
${ }^{13}$ Kegagalan bangunan adalah suatu keadaan keruntuhan bangunan dan/atau tidak berfungsinya bangunan setelah penyerahan akhir hasil jasa konstruksi.
} 
Berdasarkan ketentuan-ketentuan diatas dapat dianalisis mengenai tanggung gugat dari konsultan pengawas pada pekerjaan konstruksi terintegrasi bahwa kegagalan bangunan merupakan salah satu akibat dari kegagalan konstruksi. Kegagalan pekerjaan konstruksi dapat disebut sebagai suatu penyelewengan terhadap kontrak karena terjadi ketidaksesuaian dengan apa yang telah diperjanjikan dalam kontrak. Kegagalan tersebut dimungkinkan dilakukan oleh pengguna jasa maupun penyedia jasa baik konsultan perencana, kontraktor maupun konsultan pengawas yang meliputi tahap perencanaan, pelaksanaan, dan pengawasan. Penyedia jasa wajib bertanggung jawab atas kegagalan bangunan dalam jangka waktu paling lama 10 (sepuluh) tahun sejak tanggal penyerahan akhir. Penyedia jasa juga wajib memberikan ganti rugi atas kegagalan tersebut. Kegagalan bangunan tersebut ditetapkan oleh penilaian ahli.

Di dalam UUJK hanya ada sanksi administratif dan aspek keperdataan dalam hal terjadi sengketa antara para pihak, sedangkan sanksi pidana sudah dihapus ketentuannya. Dalam hal penyedia jasa tidak memenuhi kewajiban untuk mengganti atau memperbaiki kegagalan bangunan maka dapat dikenai sanksi administratif antara lain : peringatan tertulis; denda administratif; penghentian sementara kegiatan layanan jasa konstruksi; pencantuman dalam daftar hitam; pembekuan izin; dan/atau pencabutan izin.Konsultan pengawas berperan untuk menjamin mutu pekerjaan, sehingga jika terdapat ketidaksesuaian mutu maka hal tersebut menjadi tanggung jawab dari pengawas. Dalam pekerjaannya konsultan pengawas bekerja secara harian, karena konsultan pengawas akan mencatat semua aspek yang terjadi di lapangan secara harian, mingguan, dan bulanan. Laporan harian akan dikompilasi menjadi laporan mingguan, kemudian laporan mingguan dikompilasi menjadi laporan bulanan. Hal hal yang dicatat oleh konsultan pengawas adalah mengenai jumlah bahan, alat, tenaga kerja, cuaca dan mencatat progres pekerjaan.

\section{Penyelesaian Sengketa Kontrak Jasa Konstruksi Terintegrasi}

Kontrak kerja konstruksi menganut asas kebebasan berkontrak, maka para pihak dapat menyepakati klausula mengenai penyelesaian sengketajika dalam 
pelaksanaan kontrak tersebut terjadi sengketa dapat diselesaikan dengan cara musyawarah, mediasi, konsiliasi ,arbitrase ataupun melalui pengadilan.Dalam prakteknya para pihak memilih untuk menyelesaikan sengketa diluar pengadilan (Alternative Dispute Resolution). Ketentuan UUJK memberikan penekanan untuk digunakannya alternatif penyelesaian sengketa di luar pengadilan. Upaya penyelesaian sengketa melalui pengadilan adalah upaya akhir jika upaya penyelesaian sengketa yang lain belum menghasilkan kesepakatan. Pengadilan yang berwenang untuk mengadili perkara adalah pengadilan negeri tempat domisili para pihak berselisih, temasuk lokasi proyek yang bersangkutan yang tercantum dalam kontrak.

Perpres No. 16 Tahun 2018 juga mengatur mengenai penyelesaian sengketa kontrakantaraPPK danPenyedia,yakni dapatdilakukanmelaluilayananpenyelesaian sengketa kontrak, arbitrase, atau penyelesaian melalui pengadilan. Pengaturan lebih lanjutnya terdapat dalam Peraturan LKPP No. 18 Tahun 2018 tentang Layanan Penyelesaian Sengketa Kontrak Pengadaan Barang/ Jasa Pemerintah, yakni melalui musyawarah, konsultasi, mediasi, konsiliasi, dan arbitrase.

Penyelesaian sengketa di luar pengadilan baik berupa mediasi, konsiliasi ataupun arbitrase diberikan penekanan dalam UUJK, karena terdapat beberapa kelebihan, antara lain :

1. Kerahasiaan terjaga. Ketika menggunakan upaya penyelesaian sengketa di luar pengadilan maka kerahasiaan sengketa akan terjaga, karena proses hingga putusan penyelesaian sengketa tidak dipublikasikan seperti halnya putusan pengadilan. Dengan adanya kerahasiaan ini maka hubungan antara para pihak yang bersengketa tetap baik dan dapat melanjutkan pekerjaan;

2. Sengketa diputus oleh penengah yang mengerti tentang bidang konstruksi. Para pihak bebas untuk memilih mediator, konsiliator ataupun arbiter yang akan memutus atau memberi rekomendasi terkait sengketa yang sedang terjadi. Sehingga para pihak cenderung memilik penengah yang memiliki pengetahyan di bidang konstruksi;

3. Sengketa diselesaikan dengan waktu yang relatif singkat. Penyelesaian sengketa 
melalui jalur non - litigasi ini dilakukan secara cepat daripada penyelesaian melalui jalur pengadilan.

\section{Kesimpulan}

Terdapat tiga jenis usaha jasa konstruksi dalam Undang-Undang No. 2 tahun 2017, antara lain : usaha jasa konsultansi konstruksi; usaha pekerjaan konstruksi; dan usaha pekerjaan konstruksi terintegrasi. Pekerjaan konstruksi terintegrasi memiliki pengertian yaitu gabungan dari pekerjaan konstruksi dengan jasa konsultansi. Pekerjaan konstruksi terintegrasi dapat berupa rancang bangun (Design and Build) yang meliputi bangunan gedung dan bangunan sipil, serta perekayasaan, pengadaan dan pelaksanaan (Engineering-Procurement-Construction/EPC) yang biasa digunakan untuk pembangunan dalam industri minyak, gas bumi dan petrokimia. Pekerjaan konstruksi terintegrasi memiliki karakteristik dimana pekerjaan konstruksi tersebut dilakukan dan menjadi tanggung jawab dari satu badan usaha saja, sehingga pekerjaan dapat dilaksanakan dengan cepat,efisien, serta lebih operasioanl. Terkait pekerjaan konstruksi rancang-bangun diatur lebih khusus di dalam Peraturan Menteri PUPR No. 12/PRT/M/2017. Sedangkan untuk EPC belum ada peraturan menteri pekerjaan umum yang mengatur lebih khusus sehingga berpedoman pada FIDIC Silver Book.

Tanggung gugat adalah suatu rangkaian untuk menanggung kerugian yang diakibatkan karena kesalahan atau resiko. Tanggung gugat dari konsultan pengawas pada pekerjaan konstruksi terintegrasi jika terjadi kegagalan bangunan akibat dari kegagalan konstruksi. Kegagalan pekerjaan konstruksi dapat disebut sebagai suatu penyelewengan terhadap kontrak karena terjadi ketidaksesuaian dengan apa yang telah diperjanjikan dalam kontrak. Kegagalan tersebut dimungkinkan dilakukan oleh penyedia jasa baik konsultan perencana, kontraktor maupun konsultan pengawas yang meliputi tahap perencanaan, pelaksanaan, dan pengawasan. Penyedia jasa wajib bertanggung jawab atas kegagalan bangunan dalam jangka waktu paling lama 10 (sepuluh) tahun sejak tanggal penyerahan akhir. Penyedia jasa juga dikenai ganti rugi atas kegagalan tersebut. Jika dalam hal penyedia jasa tidak sukarela memenuhi 
kewajibannya maka dapat dikenai sanksi adminsitrasi dan jika terjadi sengketa maka penyelesaian perselisihannya ditempuh melalui antara lain musyawarah, mediasi, arbitrase, ataupun pengadilan

\section{Daftar Bacaan}

\section{Buku}

Y.Sogar Simamora, dkk., Buku Ajar Hukum Kontrak (Yuridika Fakultas Hukum Universitas Airlangga 2012).

Y.Sogar Simamora, Hukum Kontrak: Prinsip-Prinsip Hukum Kontrak Pengadaan Barang dan Jasa Pemerintah di Indonesia (Laksbang PRESindo Surabaya 2017).

\section{Jurnal}

Dwi Mariyati, 'Prinsip Hukum Dalam Penyusunan Dan Pelaksanaan Kontrak Engineering Procurement Constuction (Kontrak “EPC”)' (2018) 33 Yuridika.

Riyadi Nurcawenda R., 'Kajian Pengaruh Peranan Konsultan Pengawas Terhadap Pelaksanaan Proyek Pembangunan Pendopo Di Karawang Jawa Barat', (2018) 13 Isu Teknologi STT Mandala.

\section{Perundang-undangan}

Undang-Undang Dasar Negara Republik Indonesia Tahun 1945.

Kitab Undang-Undang Hukum Perdata / Burgerlijk wetboek.

Undang-Undang Nomor 2 Tahun 2017 tentang Jasa Konstruksi.

Undang-Undang Nomor 30 Tahun 1999 tentang Arbitrase dan Alternatif Penyelesaian Sengketa.

Peraturan Presiden Nomor 16 Tahun 2018 tentang Pengadaan Barang/Jasa Pemerintah.

Peraturan Pemerintah Republik Indonesia Nomro 54 Tahun 2016 tentang Perubahan Ketiga Atas Peraturan Pemerintah Nomor 29 Tahun 2000 Tentang Penyelenggaraan Jasa Konstruksi.

Peraturan Menteri Energi Sumber Daya Mineral Nomor 27 Tahun 2008 Tentang Kegiatan Usaha Penunjang Minyak dan Gas Bumi. 
Peraturan Menteri Pekerjaan Umum Dan Perumahan Rakyat Republik Indonesia Nomor 12/PRT/M/2017 tentang Standar Dan Pedoman Pengadaan Pekerjaan Konstruksi Terintegrasi Rancang Dan Bangun (Design And Build).

Peraturan Menteri Pekerjaan Umum Dan Perumahan Rakyat Republik Indonesia Nomor 07/PRT/M/2019 tentang Standar Dan Pedoman Pengadaan Jasa Konstruksi Melalui Penyedia.

Peraturan Lembaga Pengembangan Jasa Konstruksi Nasional Nomor 3 Tahun 2015 tentang Perubahan Pertama Atas Peraturan Lembaga Pengembangan Jasa Konstruksi Nasional Nomor 5 Tahun 2014 tentang Registrasi Usaha Jasa Konstruksi Terintegrasi.

Peraturan Lembaga Kebijakan Pengadaan Barang/Jasa Pemerintah Nomor 7 Tahun 2018 tentang Pedoman Perencanaan Pengadaan Barang/Jasa Pemerintah.

Peraturan Lembaga Kebijakan Pengadaan Barang/Jasa Pemerintah Nomor 9 Tahun 2018 tentang Pedoman pelaksanaan Pengadaan Barang/Jasa Melalui Penyedia.

Peraturan Lembaga Pengembangan Jasa Konstruksi Nasional Nomor 4 Tahun 2017Tentang Sertifikasi dan Registrasi Usaha Jasa Perencana Dan Pengawas Konstruksi. 